\title{
THE CONQUEST OF THE UNITED STATES BY SPAIN.
}

During the last year the public has been familiarized with descriptions of Spain and of Spanish methods of doing things until the name of Spain has become a symbol for a certain welldefined set of notions and policies. On the other hand, the name of the United States has always been, for all of us, a symbol for a state of things, a set of ideas and traditions, a group of views about social and political affairs. Spain was the first, for a long time the greatest, of the modern imperialistic States. The United States, by its historical origin, its traditions and its principles, is the chief representative of the rerolt and reaction against that kind of a state. I intend to show that, by the line of action now proposed to us, which we call expansion and imperialism, we are throwing away some of the most important elements of the American symbol, and are adopting some of the most important elements of the Spanish symbol. We have beaten Spain in a military conflict, but we are submitting to be conquered by her on the field of ideas and policies. Expansionism and imperialism are nothing but the old philosophies of national prosperity which have brought Spain to where she now is. Those philosophies appeal to national vanity and national cupidity. They are seductive, especially upon the first view and the most superficial judgment, and therefore it cannot be denied that they are very strong for popular effect. They are delusions, and they will lead us to ruin unless we are hardheaded enough to resist them. In any case the year 1898 is a great landmark in the history of the United States. The consequences will not be all good or all bad, for such is not the nature of societal influences. They are always mixed of good and ill, and so it will be in this case. Fifty years from now, the historian, looking back to 1898 , will no doubt see, in the course which things will have taken, consequences of the proceedings of that year, and of this present one, which will not all be bad, but you will observe that that is not a justification for a happy-go-lucky policy; that does not affect our duty to-day in all that we do to seek wisdom and prudence and to determine our actions by the best judgment which we can form.

War, expansion, and imperalism are questions of statesmanship and of nothing else. I disregard all other aspects of them, 
and all extraneous elements which have been intermingled with them. I received the other day a circular of a new educational enterprise in which it was urged that, on account of our new possessions, we ought now to devote especial study to history, political economy, and what is called political science. I asked myself, why? What more reason is there for pursuing these studies now on behalf of our dependencies than there was before to pursue them on behalf of ourselves. In our proceedings of 1898 , we made no use of whatever knowledge we had of any of these lines of study. The original and prime cause of the war was that it was a move of partisan tactics in the strife of parties at Washington. As soon as it seemed resolved upon, a number of interests began to see their advantage in it, and hastened to further it. It was necessary to make appeals to the public which would bring quite other motives to the support of the enterprise, and win the consent of classes who would never consent to either financial or political jobbery. Such appeals were found in sensational assertions which we had no means to verify, in phrases of alleged patriotism, in statements about Cuba and the Cubans which we now know to have been entirely untrue.

Where was the statesmanship of all this? If it is not an established rule of statecraft that a statesman should never impose any sacrifices on his people for anything but their own interests, then it is useless to study political philosophy any more, for this is the alphabet of it. It is contrary to honest statesmanship to imperil the political welfare of the state for party interests. It was unstatesmanlike to publish a solemn declaration that we would not seize any territory, and especially to characterize such action in advance as "criminal aggression," for it was morally certain that we should come out of any war with Spain with conquered territory on our hands, and the people who wanted the war, or who consented to it, hoped that we would do so.

We talk about "liberty" all the time in a glib and easy vay, as if liberty was a thing that men could have if they want it, and to any extent to which they want it. It is certain that a very large part of human liberty consists simply in the choice either to do a thing or to let it alone. If we decide to do it, a whole series of consequences is entailed upon us in regard to which it is exceedingly difficult, or impossible, for us to exercise any liberty at all. The proof of this from the case before us is so clear and easy that I need spend no words upon it. Here, then, you have the reason why it is a rule of sound statesman- 
ship not to embark on an adventurous policy. A statesman could not be expected to know in advance that we should come out of the war with the Philippines on our hands, but it belongs to his education to warn him that a policy of adventure and of gratuitous enterprise would be sure to entail embarrassments of some kind. What comes to us in the evolution of our own life and interests, that we must meet; what we go to seek which lies beyond that domain, is a waste of our energy and a compromise of our liberty and welfare. If this is not sound doctrine, then the historical and social sciences have nothing to teach us which is worth any trouble.

There is another observation, however, about the war which is of far greater importance; that is, that it was a gross violation of self-government. We boast that we are a self-governing people, and in this respect, particularly, we compare ourselves with pride with older nations. What is the difference after all? The Russians, whom we always think of as standing at the opposite pole of political institutions, have self-government, if you mean by it acquiescence in what a little group of people at the head of the government agree to do. The war with Spain was precipitated upon us headlong, without reflection or deliberation, and without any due formulation of public opinion. Whenever a voice was raised in behalf of deliberation and the recognized maxims of statesmanship, it was howled down in a storm of vituperation and cant. Everything was done to make us throw away sobriety of thought and calmness of judgment, and to inflate all expressions with sensational epithets and turgid phrases. It cannot be denied that everything in regard to the war has been treated in an exalted strain of sentiment and rhetoric very unfavorable to the truth. At present the whole periodical press of the country seems to be occupied in tickling the national vanity to the utmost by representations about the war which are extravagant and fantastic. There will be a penalty to be paid for all this. Nervous and sensational newspapers are just as corrupting, especially to young people, as nervous and sensational novels. The habit of expecting that all mental pabulum shall be highly spiced, and the corresponding loathing for whatever is soberly truthful, undermines character as much as any other vice. Patriotism is being prostituted into a nervous intoxication which is fatal to an apprehension of truth. It builds around us a fool's paradise, and it will lead us into errors about our position and relations just like those which we have been ridiculing in the case of Spain.

There are some now who think that it is the perfection of statesmanship to say that expansion is a fact and that it is use- 
less to discuss it. We are told that we must not cross any bridges until we come to them; that is, that we must discuss nothing in advance, and that we must not discuss anything which is past because it is irretrievable: No doubt this would be a very acceptable doctrine to the powers that be, for it would mean that they were relieved from responsibility, but it would be a marvelous doctrine to be accepted by a self-governing people. Senator Foraker has told us that we are not to keep the Philippines longer than is necessary to teach the people self-government. How one man can tell what we are to do before the constitutional authorities have decided it, I do not know. Perhaps it is a detail in our new method of selfgovernment. If his assurances are to be trusted, we are paying $\$ 20,000,000$ for the privilege of tutoring the Tagals up to liberty and self-government. I do not believe that, if the United States undertakes to govern the islands, it will ever give them up except to superior force, but the weakening of imperialism shown by this gentleman's assurances, after a few days of mild debate in the Senate, shows that agitation of the subject is not yet in vain. Then again, if we have done anything, especially if we have acted precipitately, it is a well recognized course of prudent behavior to find out where we are, what we have done, and what the new situation is into which we have come. Then, too, we must remember that when the statesman lays a thing down the historian takes it up, and he will group it with historical parallels and contrasts. There is a set of men who have always been referred to, in our Northern States, for the last thirty years, with especial disapproval. They are those Southerners who, in $186 x$, did not believe in secession, but, as they said: "Went with their States." They have been condemned for moral cowardice. "Yet within a year it has become almost a doctrine with us that patriotism requires that we should hold our tongues while our interests, our institutions, our most sacred traditions, and our best established maxims have been trampled underfoot. There is no doubt that moral courage is the virtue which is more needed than any other in the modern democratic state, and that truckling to popularity is the worst political vice. The press, the platform, and the pulpit have all fallen under this vice, and there is evidence that the university also, which ought to be the last citadel of truth, is succumbing to it likewise. I have no doubt that the conservative classes of this country will yet look back with great regret to their acquiescence in the events of 1898 and the doctrines and precedents which have been silently established. 
Let us be well-assured that self-government is not a matter of flags and Fourth of July orations, nor yet of strife to get offices. Eternal vigilance is the price of that as of every other political good. The perpetuity of self-government depends on the sound political sense of the people, and sound political sense is a matter of habit and practice. We can give it up and we can take instead pomp and glory. That is what Spain did. She had as much self-government as any country in Europe at the beginning of the sixteenth century. The union of the smaller states into one big one gave an impulse to her national feeling and national development. The discovery of America put into her hands the control of immense territories. National pride and ambition were stimulated. Then came the struggle with France for world-dominion, which resulted in absolute monarchy and bankruptcy for Spain. She lost self-government and saw her resources spent on interests which were foreign to her, but she could talk about an empire on which the sun never set, and boast of her colonies, her gold mines, her fleets and armies and debts. She had glory and pride, mixed, of course, with defeat and disaster, such as must be experienced by any nation on that course of policy, and she grew weaker in her industry and commerce, and poorer in the status of the population all the time. She has never been able to recover real self-government yet. If we Americans believe in self-government why do we let it slip away from us? Why do we barter it away for military glory as Spain did?

There is not a civilized nation which does not talk about its civilizing mission just as grandly as we do. The English, who really have more to boast of in this respect than any body else, talk least about it, but the Phariseeism with which they correct and instruct other people has made them hated all over the globe. The French believe themselves the guardians of the highest and purest culture, and that the eyes of all mankind are fixed on Paris, from whence they expect oracles of thought and taste. The Germans regard themselves as charged with a mission, especially to us Americans, to save us from egoism and materialism. The Russians, in their books and newspapers, talk about the civilizing mission of Russia, in language that might be translated from some of the finest paragraphs in our imperialistic newspapers. The first principle of Mohammedanism is that we Christians are dogs and infidels, fit only to be enslaved or butchered by Moslems. It is a corollary that wherever Mohammedanism extends, it carries, in the belief of its votaries, the highest blessings, and that the whole human 
race would be enormously elevated if Mohammedanism should supplant Christianity everywhere. To come last to Spain, the Spaniards have, for centuries, considered themselves the most zealous and self-sacrificing Christians, especially charged by the Almighty, on this account, to spread true religion and civilization over the globe. They think themselves free and noble, leaders in refinement and the sentiments of personal honor, and they despise us as sordid money-grabbers and heretics. I could bring you passages from peninsular authors of the first rank about the grand role of Spain and Portugal in spreading freedom and truth. Now each nation laughs at all the others when it observes these manifestations of national vanity. You may rely upon it that they are ali ridiculous by virtue of these pretensions, including ourselves. The point is that each of them repudiates the standards of the others, and the outlying nations, which are to be civilized, hate all the standards of civilized men. We assume that what we like and practice, and what we think better, must come as a welcome blessing to Spanish-Americans and Philippinos. This is grossly and obviously untrue. They hate our ways. They are hostile to our ideas. Our religion, language, institutions and manners offend them. They like their. own ways, and if we appear amongst them as rulers, there will be social discord on all the great departments of social interest. The most important thing which we shall inherit from the Spaniards will be the task of suppressing rebellions. If the United States takes out of the hands of Spain her mission, on the ground that Spain is not executing it well, and if this nation in its turn, attempts to be school-mistress to others, it will shrivel up into the same vanity and self-conceit of which Spain now presents an example. To read our current literature one would think that we were already well on the way to it. Now, the great reason why all these enterprises which begin by saying to somebody else: We know what is good for you, better than you know yourself, and we are going to make you do it-are false and wrong, is that they violate liberty; or, to turn the same statement into other words: the reason why liberty, of which we Americans talk so much; is a good thing, is that it means leaving people to live out their own lives in their own way, while we do the same. If we believe in liberty, as an American principle, why do we not stand by it? Why are we going to throw it away to enter upon a Spanish policy of dominion and regulation?

The United States cannot be a colonizing nation for a long time yet. We have only 23 persons to the square mile in the 
United States without Alaska. The country can multiply its population by 13 , that is, the population could rise above.a billion, before the whole country would be as densely populated as Rhode Island is now. There is, therefore, no pressure of population, which is the first condition of rational expansion, unless we could buy another territory like the Mississippi Valley with no civilized population in it. If we could do that it would postpone the day of over-population still further, and make easier conditions for our people in the next generations. In the second place, the islands which we have taken from Spain never can be the residence of American families, removing and settling to make their homes there. The climatic conditions forbid it. Although Spaniards have established themselves in Spanish America, even in the tropics, the evils of Spanish rule have largely arisen from the fact that Spaniards have gone to the colonies as adventurers, eager to make fortunes as quickly as possible, that they might return to Spain to enjoy them. That the relation of our people to these possessions will have that character is already apparent. It is, therefore, inaccurate to speak of a colonial system in describing our relation to these dependencies, but as we have no other term, let us use this one and inquire what kind of a colonial system we are to establish.

I. Spain stands, in modern history, as the first state to develop and apply a colonial system to her outlying possessions. Her policy was to exclude absolutely all non-Spaniards from her subject territories, and to exploit them for the benefit of Spain, without much regard for the aborigines or the colonists. The cold and unnecessary cruelty of the Spaniards to the aborigines is appalling, even when compared with the treatment of the aborigines by other Europeans. A modern economist stands aghast at the economic measures adopted by Spain, as well in regard to her domestic policy as to her colonies. It seems as if those measures could only have been inspired by some demon of folly, they were so destructive to her prosperity. She possesses a large literature from the last three centuries, in which her publicists discuss with amazement the question whether it was a blessing or a curse to get the Indies, and why, with all the supposed conditions of prosperity in her hands, she was declining all the time. We now hear it argued that she is well rid of her colonies, and that, if she will devote her energies to her internal development, and rid her politics of the corruption of colonial officials and interests, she may be regenerated. That is a rational opinion. It is the best diagnosis of 
her condition, and the best prescription of a remedy which the occasion has called forth. But what, then, will happen to the state which has taken over her colonies? I can see no answer except that that nation, with them, has taken over the disease, and that it now is to be corrupted by exploiting dependent communities just as she has been. That it stands exposed to this danger is undeniable.

It would not be becoming to try, in a paragraph, to set forth the causes of the decadence of Spain, and although the economic history of that country has commanded such attention from me as I could give to it consistently with other obligations, yet I could not feel prepared to do any justice to that subject; but one or two features of the history can be defined with confidence, and they are such as are especially instructive for us.

In the first place, Spain never intended, of set purpose, to ruin the material prosperity of herself or her colonies. Her economic history is one long lesson to prove that any prosperity policy is a delusion and a path to ruin. There is no economic lesson which the people of the United States need to take to heart more than that. In the second place the Spanish mistakes arose, in part, from confusing the public treasury with the national wealth. They thought that, when gold flowed into the public treasury, that was the same as an increase of wealth of the people. It really meant that the people were bearing the burdens of the imperial system and that the profits of it went into the public treasury, that is, into the hands of the king. It was no wonder, then, that as the burdens grew greater, the people grew poorer. The king spent the revenues in extending the imperial system in Germany, Italy and the Netherlands, so that the revenues really became a new cause of corruption and decay. The only people who were well off, in the midst of the increasing distress, were the ecclesiastics and nobles, who were protected by entails and charters, which, in their turn, were a new cause of restriction and destruction to the industries of the country. As to the treatment of the aborigines in the outlying possessions of Spain the orders from the home government were as good as could possibly be desired. No other European government issued any which were nearly so enlightened or testified to such care about that matter. Spanish America is still covered with institutions founded by Spain for the benefit of the aborigines, so far as they have not been confiscated or diverted to other uses. Nevertheless the Spanish rule nearly exterminated the aborigines in $15^{\circ}$ years. The Pope gave them into servitude to the Spaniards. The Spaniards 
regarded them as savages, heretics, beasts, not entitled to human consideration. Here you have the great explanation of man's inhumanity to man. When Spaniards tortured and burned Protestants and Jews it was because, in their minds, Protestants and Jews were heretics, that is to say, were beyond the pale, were abominable, were not entitled to human consideration. Humane men and pious women felt no more compunctions at the sufferings of Protestants and Jews than we would at the execution of mad dogs or rattlesnakes. There are plenty of people in the United States to-day who regard negroes as human beings, perhaps, but of a different order from white men, so that the ideas and social arrangements of white men cannot be applied to them with propriety. Others feel the same way about Indians. This attitude of mind, wherever you meet with it, is what causes tyranny and cruelty. It is this disposition to decide off-hand that some people are not fit for liberty and selfgovernment which gives relative truth to the doctrine that all men are equal, and inasmuch as the history of mankind has been one long story of the abuse of some by others, who, of course, smoothed over their tyranny by some beautiful doctrines of religion, or ethics, or political philosophy, which proved that it was all for the best good of the oppressed, therefore the doctrine that all men are equal has come to stand as one of the corner-stones of the temple of justice and truth. It was set up as a bar to just this notion that we are so much better than others that it is liberty for them to be governed by us.

The Americans have been committed from the outset to the doctrine that all men are equal. We have elevated it into an absolute doctrine as a part of the theory of our social and political fabric. It has always been a domestic dogma in spite of its absolute form, and as a domestic dogma it has always stood in glaring contradiction to the facts about Indians and negroes, and to our legislation about Chinamen. In its absolute form it must, of course, apply to Kanakas, Malays, Tagals and Chinese just as much as to Yankees, Germans and Irish. It is an astonishing event that we have lived to see American arms carry this domestic dogma out where it must be tested in its application to uncivilized and half-civilized peoples. At the first touch of the test we throw the doctrine away and adopt the Spanish doctrine. We are told by all the imperialists that these people are not fit for liberty and self-government; that it is rebellion for them to resist our beneficence; that we must send fleets and armies to kill them if they do it; that we must devise a government for them and administer it ourselves; that 
we may buy them or sell them as we please, and dispose of their "trade" for our own advantage. What is that but the policy of Spain to her dependencies? What can we expect as a consequence of it? Nothing but that it will bring us where Spain is now.

But, then, if it is not right for us to hold these islands as dependencies, you may ask me whether I think that we ought to take them into our Union, at least some of them, and let them help to govern us. Certainly not. If that question is raised, then the question whether they are, in our judgment, fit for self-government or not is in order. The American people, since the civil war, have to a great extent lost sight of the fact that this state of ours, the United States of America, is a confederated state of a very peculiar and artificial form. It is not a state like the states of Europe, with the exception of Switzerland. The field for dogmatism in our day is not theology; it is political philosophy. "Sovereignty" is the most abstract and metaphysical term in political philosophy. Nobody can define it. For this reason it exactly suits the purposes of the curbstone statesman. He puts into it whatever he wants to get out of it again, and he has set to work lately to spin out a proof that the United States is a great imperalistic state, although the Constitution, which tells us just what it is, and what it is not, is there to prove the contrary.

The thirteen colonies, as we all know, were independent commonwealths with respect to each other. They had little sympathy and a great deal of jealousy. They came into a union with each other upon terms which were stipulated and defined in the Constitution, but they united only unwillingly and under the pressure of necessity. What was at first only a loose combination or alliance has been welded together into a great state by the history of a century. Nothing, however, has altered that which was the first condition of the Union, viz., that all the States members of it should be on the same plane of civilization and political development; that they should all hold the same ideas, traditions and political creed; that their social standards and ideals should be such as to maintain cordial sympathy between them. The civil war arose out of the fact that this condition was imperfectly fulfilled. At other times actual differences in standpoint and principle, or in ideals and opinion, have produced discord within the confederation. Such crises are inevitable in any confederated state. It is the highest statesmanship in such a system to avoid them, or smooth them over, and above all, never to take in voluntarily 
any heterogeneous elements. The prosperity of such a state depends on closer and closer sympathy between the parts in order that differences which arise may be easily harmonized. What we need is more intension, not more extension.

It follows, then, that it is unwisdom to take into a state like this any foreign element which is not congenial to it. Any such element will act as a solvent upon it. Consequently we are brought by our new conquests face to face with this dilemma: we must either hold them as inferior possessions, to be ruled and exploited by us after the fashion of the old colonial system, or we must take them in on an equality with ourselves, where they will help to govern us and to corrupt a political system which they do not understand, and in which they cannot participate. From that dilemma there is no escape except to give them independence and to let them work out their own salvation or go without it. Hayti has been independent for a century, and has been a theatre of revolution, tyranny and bloodshed all the time. There is not a Spanish-American state which has proved its capacity for self-government as yet. It is a fair question whether any one of them would have been worse off than it is to-day if Spanish rule had been maintained in it. The chief exception is Mexico. Mr. Lummis, an American, has recently published a book on Mexico, in which he tells us that we would do well to go to school to Mexico for a number of important public interests, but Mexico has been, for ro or I5 years, under a dictator, and the republican forms have been in abeyance. What will happen there when the dictator dies nobody knows. The doctrine that we are to take away from other nations any possessions of theirs which we think that we could manage better than they are managing them, or that we are to take in hand any countries which we do not think capable of self-government, is one which will lead us very far. With that doctrine in the background, our politicians will have no trouble to find a war ready for us the next time that they come around to the point where they think that it is time for us to have another. We are told that we must have a big army hereafter. What for; unless we propose to do again bye-and-bye what we have just done? In that case our neighbors have reason to ask themselves who we will attack next. They must begin to arm, too, and by our act the whole western world is plunged into the distress under which the eastern world is groaning. Here is another point in regard to which the conservative elements in the country are making a great mistake to allow all this militarism and imperialism to go on 
without protest. It will be established as a rule that, whenever political ascendancy is threatened, it can be established again by a little war, filling the minds of the people with glory and diverting their attention from their own interests. Hardheaded old Benjamin Franklin hit the point when, referring back to the days of Marlborough, he talked about the "pest of glory." The thirst for glory is an epidemic which robs a people of their judgment, seduces their vanity, cheats them of their interests, and corrupts their consciences.

This country owes its existence to a revolt against the colonial and navigation system which, as I have said, Spain first put in practice. The English colonial system never was even approximately so harsh and tyrannical as that of Spain. The first great question which arose about colonies in England was whether they were parts of the possessions of the king of England or part of the dominion of the crown. The constitutional difference was great. In the one case they were subject to the king and were not under the constitutional guarantees; in the other case they were subject to the Parliament and were under the constitutional guarantees. This is exactly the same question which arose in the middle of this century in this country about territories, and which helped to bring on the civil war. It is already arising again. It is the question whether the Constitution of the United States extends over all men and territory owned by the United States, or whether there are to be grades and planes of rights for different parts of the dominions over which this flag waves. This question already promises to introduce dissensions amongst us which will touch the most vital elements in our national existence.

The constitutional question, however, goes even deeper than this. Of the interpretation of clauses in the Constitution I am not competent to speak, but the Constitution is the organic law of this Confederated State in which we live, and therefore it is the description of it as it was planned and as it is. The question at stake is nothing less than the integrity of this State in in its most essential elements. The expansionists have recognized this fact by already casting the Constitution aside. 'The military men, of course, have been the first to do this. It is of the essence of militarism that under it military men learn to despise Constitutions, to sneer at Parliaments, and to look with contempt on civilians. Some of the imperialists are not ready to go quite so fast, as yet. They have remonstrated against the military doctrine, but that only proves that the military men see the point at issue better than the others do. Others say 
that if the legs of the Constitution are too short to straddle the gulf between the old policy and the new, they can be stretched a little, a view of the matter which is as flippant as it is in bad taste. It would require too much time to notice the various contemptuous and jaunty references to the Constitution which every day brings to our notice, and from the same class, at least, who, two years ago, were so shocked at a criticism of the interpretation of the Constitution which was inserted in the Chicago platform.

The question of imperialism, then, is the question whether we are going to give the lie to the origin of our own national existence, by establishing a colonial system of the old Spanish type, even if we have to sacrifice our existing civil and political system to do it. I submit that it is a strange incongruity to uttter grand platitudes about the blessings of liberty, etc., etc., which we are going to impart to these people, and to begin by refusing to extend the Constitution over them, and still more, by throwing the Constitution into the gutter here at home. If you take away the Constitution, what is American liberty and all the rest? Nothing but a lot of phrases.

Some will answer me that they do not intend to adopt any Spanish colonial system; that they intend to imitate the modern English policy with respect to colonies. The proudest fact in the history of England is that, since the Napoleonic wars, she has steadily corrected abuses, amended her institutions, redressed grievances, and so has made her recent history a story of amelioration of all her institutions, social, political and civil. To do this she has had to overcome old traditions, established customs, vested rights, and all the other obstacles which retard or prevent social improvement. The consequence is that the traditions of her public service, in all its branches, have been purified, and that a body of men has grown up who have a noble spirit, high motives, honorable methods, and excellent standards. At the same time the policy of the country has been steadily growing more and more enlightened in regard to all the great interests of society. These triumphs of peace are far greater than any triumphs of war. It takes more national grit to correct abuses than to win battles. England has shown herself very willing indeed to learn from us whatever we could teach, and we might learn a great deal from her on matters far more important than colonial policy. Her reform of her colonial policy is only a part, and perhaps a consequence, of the improvements made elsewhere in her political system. 
We have had some experience this last summer in the attempt to improvise an army. We may be very sure that it is equally impossible to improvise a colonial system. The present English colonial system is aristocratic. It depends upon a large body of specially trained men, acting under traditions which have become well established, and with a firm esprit de corps. Nobody can get into it without training. The system is foreign to our ideas, tastes and methods. It would require a long time and radical changes in our political methods, which we are not as yet at all disposed to make, to establish any such thing here, and then it would be an initation. Moreover, England has three different colonial systems, according to the development of the resident population in each colony or dependency, and the selection of the one of these three systems which we will adopt and apply involves all the difficulties which I have been discussing.

There is, however, another objection to the English system. A great many people talk about the revenue which we are to get from these possessions. If we attempt to get any revenues from them we shall repeat the conduct of England towards her colonies, against which they revolted. England claimed that it was reasonable that the colonies should pay their share of imperial expenses which were incurred for the benefit of all. I have never been able to see why that was not a fair demand. As you know, the colonies spurned it with indignation, on the ground that the taxation, being at the discretion of a foreign power, might be made unjust. Our historians and publicists have taught us that the position of the colonists was right and heroic, and the only one worthy of freemen. The revolt was made on the principle of no taxation, not on the size of the tax. The colonists would not pay a penny. Since that is so, we cannot get a penny of revenue from the dependencies, even for their fair share of imperial expenditures, without burning up all our histories, revising all the great principles of our heroic period, repudiating our great men of that period, and going over to the Spanish doctrine of taxing dependencies at the discretion of the governing state. Already one of these dependencies is in arms struggling for liberty against us. Read the threats of the imperialists against these people, who dare to rebel against us, and see whether I am misstating or exaggerating the corruption of imperialism on ourselves. The question is once more, whether we are prepared to repudiate the principles which we have been insisting on for $15^{\circ}$ years, and to embrace those of which Spain is the oldest and most conspicuous representative, or not. 
In regard to this matter of taxation and revenue, the present English colonial system is as unjust to the mother country as the old system was to the colonies, or more so. The colonies now tax the mother country. She pays large expenses for their advantage, for which they return nothing. They set up tax barriers against her trade with them. I do not believe that the United States will ever consent to any such system, and I am clear in the opinion that they never ought to. If the colonies ought not to be made tributary to the mother country, neither ougint the mother country to be made tributary to them. The proposition to imitate England's colonial policy is evidently made without the necessary knowledge of what it means, and it proves that those who thrust aside prudent objections by declaring off-hand that we will imitate England have not any serious comprehension of what it is that they propose to us to do.

The conclusion of this branch of the subject is that it is fundamentally antagonistic to our domestic system to hold dependencies which are unfit to enter into the Union. Our system cannot be extended to take them in, or adjusted to them to keep them out without sacrificing its integrity. If we take in dependencies, which, as we now agree, are not fit to come in as States, there will be constant political agitation to admit them as States, for such agitation will be fomented by any party which thinks that it can win votes in that way. It was an enormous blunder in statecraft to engage in a war which was sure to bring us into this predicament.

II. It seems as if this new policy was destined to thrust a sword into every joint in our historical and philosophical system. Our ancestors revolted against the colonial and navigation system, but, as soon as they got their independence, they fastened a navigation system on themselves. The consequence is that our industry and commerce are to-day organized under a restrictive system which is the direct offspring of the old Spanish restrictive system, and is based on the same ideas of economic policy, viz., that statesmen can devise a prosperity policy for a country, which will do more for it than a spontaneous development of the energy of the people and the resources of the territory would do. On the other hand, inside of the Union we have established the grandest experiment in absolute free trade that has ever existed. The combination of the two is not new, because it is just what Colbert tried in France, but it is original here, and is an interesting result of the presence in men's minds of two opposite philosophies, the 
adjustment of which has never yet been fought out. The extension of our authority over these new territories forces the inconsistency between our internal and our external policy out of the field of philosophy into that of practical politics. Whereever the boundary line of the national system falls we have one rule inside of it and another outside of it. Are the new territories to be taken inside or to. be treated as outside? If we develop this dilemma, we shall see that it is of the first importance.

If we treat the dependencies as inside the national system, we must have absolute free trade with them. Then, if, on the policy of the "open door," we allow all others to go to them on the same terms as ourselves, the dependencies will have free trade with all the world, while we are under the restrictive system ourselves. Then, too, the dependencies can obtain no Ievenues by import duties.

If we take the other branch of the dilemma and treat the dependencies as outside of our national policy, then we must shut out their products from our market by taxes. If we do this on the policy of the "open door," then any taxes which the islands lay upon imports from elsewhere, they must also lay upon imports from us. Then they and we will be taxing each other. If we go upon the protectionist policy, we shall determine our taxes against them, and theirs against other nations, and we shall let them lay none against us. That is exactly the Spanish system. Under it the colonies will be crushed between the upper and the nether mill-stone. They will revolt against us for just the same reason for which they revolted against Spain.

I have watched the newspapers with great interest for six months, to see what indications were presented of the probable currents of opinion on the dilemma which $I$ have described. There have been but few. A few extreme protectionist newspapers have truculently declared that our protective system was to be extended around our possessions, and that everybody else was to be excluded from them. From a number of interviews and letters, by private individuals, I select the following as expressing well what is sure to be the view of the unregenerate man, especially if he has an interest to be protected as this writer had:

"I am opposed to the 'open door' policy, as I understand it. To open the ports of our new territories free to the world would have the effect of cheapening or destroying many of the benefits of territorial acquisition, which has cost us blood and 
money. As a nation we are well qualified to develop and handle the trade of our new possessions, and by permitting others to come in and divide the advantages and profits of this trade we not only wrong our own citizens, who should be given preference, but exhibit a weakness that ill becomes a nation of our prominence."

This is exactly the view which was held in Spain, France, Holland and England, in the I 8 th century, and upon which the navigation system, against which our fathers revolted, was founded. If we adopt this view we may count upon it that we shall be embroiled in constant wars with other nations, which will not consent that we should shut them out of parts of the earth's surface until we prove that we can do it by force. Then we shall be parties to a renewal of all the I8th century wars for colonies, for supremacy on the sea, for "trade," as the term is used, for world supremacy, and for all the rest of the heavy follies from which our fathers fought to free themselves. That is the policy of Russia and France at the present time, and we have before our eyes proofs of its effect on the peace and welfare of mankind.

Our modern protectionists have always told us that the object of their policy is to secure the home market. They have pushed their system to an extravagant excess. The free traders used to tell them that they were constructing a Chinese wall. They answered that they wished we were separated from other nations by a gulf of fire. Now it is they who are crying out that they are shut in by a Chinese wall. When we have shut all the world out, we find that we have shut ourselves in. The protective system is applied especially to certain selected lines of production. Of course these are stimulated out of proportion to the requirements of the community, and so are exposed to sharp fluctuations of high profits and over-production. At great expense and loss we have carried out the policy of the home market, and now we are called upon at great expense and loss to go out and conquer territory in order to widen the market. In order to have trade with another community the first condition is that we must produce what they want, and they must produce what we want. That is the economic condition. The second condition is that there must be peace and security, and freedom from arbitrary obstacles interposed by government. This is the political condition. If these conditions are fulfilled, there will be trade, no matter whether the two communities are in one body politic or not. If these conditions are not fulfilled, there will be no trade, no matter what fiag 
floats. If we want more trade we can get it any day by a reciprocity treaty with Canada, and it will be larger and more profitable than that of all the Spanish possessions. It will cost us nothing to get it. Yet while we were fighting for Porto Rico and Manilla, and spending three or four hundred millions to get them, negotiations with Canada failed through the narrow-mindedness and bigotry which we brought to the negotiation. Conquest can do nothing for trade except to remove the political obstacles which the conquered could not, or would not, remove. From this it follows that the only justification for territorial extension is the extension of free and enlightened policies in regard to commerce. Even then extension is an irksome necessity. The question always is, whether you are taking an asset or a liability. Land grabbing means properly taking territory and shutting all the rest of the world out of it, so as to exploit it ourselves. It is not land grabbing to take it and police it and throw it open to all. This is the policy of the "open door." Our external commercial policy is, in all its principles, the same as that of Spain. We had no justification, on that ground, in taking anything away from her. If we now seek to justify ourselves, it must be by going over to the free policy, but, as I have shown, that forces to a crisis the contradiction between our domestic and our external policy as to trade. It is very probable, indeed, that the destruction of our restrictive system will be the first good result of expansion, but my object here has been to show what a network of difficulties environ us in the attempt to establish a commercial policy for these dependencies. We have certainly to go through years of turmoil and political bitterness, with all the consequent chances of internal dissension, before these difficulties can be overcome.

III. Another phenomenon which deserves earnest attention from the student of cotemporaneous history and of the trend of political institutions, is the failure of the masses of our people to perceive the inevitable effect of imperialism on democracy. On the 29th of last November the Prime Minister of France was quoted in a cable dispatch as follows: "For twenty-eight years we have lived under a contradiction. The army and democracy subsist side by side. The maintenance of the traditions of the army is a menace to liberty, yet they assure the safety of the country and its most sacred duties."

That antagonism of democracy and militarism is now coming to a crisis in France, and militarism is sure to win, because the French people would make any other sacrifice 
rather than diminish their military strength. In Germany the attempt has been going on for thirty years to establish constitutional government with parliamentary institutions. The parts of the German system are at war with each other. The Emperor constantly interferes with the operation of the system and utters declarations which are entirely personal. $\mathrm{He}$ is not responsible and cannot be answered or criticised. The situation is not so delicate as in France, but it is exceedingly unstable. All the desire of Germans for self-government and civil liberty runs out into socialism, and socialism is repressed by force or by trickery. The conservative classes of the country acquiesce in the situation while they deplore it. The reason is because the Emperor is the war-lord. His power and authority are essential to the military strength of the state in face of its neighbors. That is the preponderating consideration to which everything else has to yield, and the consequence of it is that there is to-day scarcely an institution in Germany except the army.

Everywhere you go on the Continent of Europe at this hour you see the conflict between militarism and industrialism. You see the expansion of industrial power pushed forward by the energy, hope and thrift of men, and you see the development arrested, diverted, crippled and defeated by measures which are dictated by military considerations. At the same time the press is loaded down with discussions about political economy, political philosophy and social policy. They are discussing poverty, labor, socialism, charity, reform and social ideals, and are boasting of enlightenment and progress, at the same time that the things which are done are dictated by none of these considerations, but only by military interests. It is militarism which is eating up all the products of science and art, defeating the energy of the population and wasting its savings. It is militarism which forbids the people to give their attention to the problems of their own welfare and to give their strength to the education and comfort of their children. It is militarism which is combatting the grand efforts of science and art to ameliorate the struggle for existence.

The American people believe that they have a free country, and we are treated to grandiloquent speeches about our flag and our reputation for freedom and enlightenment. The common opinion is that we have these things because we have chosen and adopted them, because they are in the Declaration of Independence and the Constitution. We suppose, therefore, that we are sure to keep them and that the follies of other 
people are things which we can hear about with complacency. People say that this country is like no other; that its prosperity proves its exceptionality, and so on. These are popular errors which in time will meet with harsh correction. The United States is in a protected situation. It is easy to have equality where land is abundant, and where the population is small. It is easy to have prosperity where a few men have a great continent to exploit. It is easy to have liberty when you have no dangerous neighbors, and when the struggle for existence is easy. There are no severe penalties, under such circumstances, for political mistakes. Democracy is not then a thing to be nursed and defended, as it is in an old country like France. It is rooted and founded in the economic circumstances of the country. The orators and constitution-makers do not make democracy. They are made by it. This protected position, however, is sure to pass away. As the country fills up with population, and the task of getting a living out of the ground becomes more difficult, the struggle for existence will become harder, and the competition of life more severe. Then liberty and democracy will cost something, if they are to be maintained.

Now what will hasten the day when our present advantages will wear out and when we shall come down to the conditions of the older and densely populated nations? The answer is: war, debt, taxation, diplomacy, a grand governmental system, pomp, glory, a big army and navy, lavish expenditures, political jobbery-in a word, imperialism. In the old days the democratic masses of this country, who knew little about our modern doctrines of social philosophy, had a sound instinct on these matters, and it is no small ground of political disquietude to see it decline. They resisted every appeal to their vanity in the way of pomp and glory which they knew must be paid for. They dreaded a public debt and a standing army. They were narrow-minded and went too far with these notions, but they were, at least, right, if they wanted to strengthen democracy.

The great foe of democracy now and in the near future is plutocracy. Every year that passes brings out this antagonism more distinctly. It is to be the social war of the zoth century. In that war militarism; expansion and imperialism will all favor plutocracy. In the first place, war and expansion will favor jobbery, both in the dependencies and at home. In the second place, they will take away the attention of the people from what the plutocrats are doing. In the third place, they will cause large expenditures of the people's money, the return for 
which will not go into the treasury, but into the hands of a few schemers. In the fourth place, they will call for a large public debt and taxes, and these things especially tend to make men unequal, because any social burdens bear more heavily on the weak than on the strong, and so make the weak weaker and the strong stronger. Therefore expansion and imperialism are a grand onslaught on democracy.

The point which I have tried to make in this lecture is that expansion and imperialism?are at war with the best traditions, principles and interests of the American people, and that they will plunge us into a network of difficult problems and political perils, which we might have avoided, while they offer us no corresponding advantage in return.

Of course "principles," phrases and catchwords are always invented to bolster up any policy which anybody wants to recommend. So in this case. The people who have led us on to shut ourselves in, and who now want us to break out, warn us against the terrors of "isolation." Our ancestors all came here to isolate themselves from the social burdens and inherited errors of the old world. When the others are all over ears in trouble, who would not be isolated in freedom from care? When the others are crushed under the burden of militarism, who would not be isolated in peace and industry? When the others are all struggling under debt and taxes, who would not be isolated in the enjoyment of his own earnings for the benefit of his own family? When the rest are all in a quiver of anxiety, lest at a day's notice they may be involved in a social cataclysm, who would not be isolated out of reach of the disaster? What we are doing is that we are abandoning this blessed isolation to run after a share in the trouble.

The expansionists answer our remonstrances on behalf of the great American principles by saying that times have changed, and that we have outlived the fathers of the republic and their doctrines. As far as the authority of the great men is concerned, that may well be sacrificed without regret. Authority of persons and names is a dangerous thing. Let us get at the truth and the right. I, for my part, am also afraid of the great principles, and I would make no fight on their behalf. In the ten years before the Revolution our ancestors invented a fine lot of "principles" which they thought would help their case. They repudiated many of them as soon as they got their independence, and the rest of them have since made us a great deal of trouble. I have examined them all critically, and there is not one of them which I consider sound, as it is popularly under- 
stood. I have been denounced as a heretic on this account by people who now repudiate them all in a sentence. But this only clears the ground for the real point. There is a consistency of character for a nation as well as for a man A man who changes his principles from week to week is destitute of character and deserves no confidence. The great men of this nation were such because they embodied and expressed the opinion and sentiments of the nation in their time. Their names are something more than clubs with which to knock an opponent down when it suits one's purpose, but to be thrown away with contempt when they happen to be on the other side. So of the great principles; whether some of us are skeptical about their entire validity, and want to define and limit them somewhat, is of little importance. If the nation has accepted them, sworn by them, founded its legislation on them, imbedded them in the decisions of its courts, and then if it throws them away at six months' warning, you may depend upon it that that nation will suffer in its moral and political rectitude a shock of the severest kind. Three years ago we were ready to fight Great Britain to make her arbitrate a quarrel which she had with Venezuela. The question about the Maine was the fittest subject for arbitration that ever arose between two nations, and we refused to listen to such a proposition. Three years ago, if you had said that any proposition put forth by anybody was "English," he might have been mobbed in the streets. Now the English are our beloved friends, and we are going to try to imitate them and adopt their way of doing things. They are encuuraging us to go into difficulties, first because our hands will be full and we will be unable to interfere elsewhere, and secondly, because if we are in difficulties we shall need allies, and they think that they will be our first choice as such. Some of our public journals have been pouring out sentimental drivel for years about arbitration, but last summer they turned around and began to pour out sentimental drivel about the benefits of war. We congratulate ourselves all the time on the increased means of producing wealth, and then we take the opposite fit and commit some great folly in order to prove that there is something grander than the pursuit of wealth. Three years ago we were on the verge of a law to keep immigrants out who were not good enough to be in with us. Now we are going to take in $8,000,000$ barbarians and semi-barbarians, and we are paying $\$ 20.000,000$ to get them. For thirty years the negro has been in fashion. He has had political value and has been petted. Now we have made friends with the Southerners. 
They and we are hugging each other. We are all united. The negro's day is over. He is out of fashion. We cannot treat him one way and the Malays, Tagals and Kanakas another way. A Southern senator two or three days ago thanked an expansionist senator from Connecticut for enunciating doctrines which proved that, for the last thirty years, the Southerners have been right all the time, and his inference was incontrovertible. So the "great principles" change all the time, or, what is far more important, the phrases change. Some go out of fashion; others come in, but the phrase-makers are with us all the time. So when our friends the expansionists tell us that times have changed, what it means is that they have a whole set of new phrases which they want to force into the place of the old ones. The new ones are certainly no more valid than the old ones. All the validity that the great principles ever had they have now. Anybody who ever candidly studied them and accepted them for no more than they were really worth can stand by them now as well as ever. The time when a maxim or principle is worth something is when you are tempted to violate it.

Another answer which the imperialists make is that Americans can do anything. They say that they do not shrink from responsibilities. They are willing to run into a hole, trusting to luck and cleverness to get out. There are some things that Americans cannot do. Americans cannot make 2 and $2=5$. You may answer that that is an arithmetical impossibility and is not in the range of our subject. Very well: Americans cannot collect $\$ 2$ a gallon tax on whisky. They tried it for many years and failed. That is an economic or political impossibility, the roots of which are in human nature. It is as absolute an impossibility on this domain as the former on the domain of mathematics. So far as yet appears, Americans cannot govern a city of roo,ooo inhabitants so as to get comfort and convenience in it at a low cost and without jobbery. The fire department of this city is now demoralized by political jobbery. Spain and all her possessions are not worth as much to you and me as the efficiency of the fire department of New Haven. The Americans in Connecticut cannot abolish the rotten borough system. The English abolished their rotten borough system seventy years ago, in spite of nobles and landlords. We cannot abolish ours in spite of the small towns. Americans cannot reform the pension list. Its abuses are rooted in the methods of democratic self-government, and no one dares to touch them. It is very doubtful indeed if Americans can keep up an army of 100,000 men in time of peace. Where can 
roo,000 men be found in this country who are willing to spend their lives as soldiers ? or, if they are found, what pay will it require to induce them to take this career? Americans cannot disentangle their currency from the confusion into which it was thrown by the civil war, and they cannot put their currency. on a simple, sure and sound basis which would give stability to the business of the country. This is a political impossibility. Americans cannot assure the suffrage to negroes throughout the United States. They have tried it for thirty years, and now, contemporaneously with this war with Spain, it has been finally demonstrated that it is a failure. Inasmuch as the negro is now out of fashion no further attempt to accomplish this purpose will be made. It is an impossibility on account of the complexity of our system of State and federal government. If I had time to do so, I could go back over the history of negro suffrage and show you how curbstone arguments, exactly analogous to the arguments about expansion, were used to favor it, and how objections were thrust aside in this same blustering and senseless manner in which objections to imperialism are met. The ballot, we were told, was an educator and would solve all difficulties in its own path as by magic. Worse still: Americans cannot assure life, liberty and the pursuit of happiness to negroes inside of the United States. "When the negro postmaster's house was set on fire in the night in South Carolina, and not only he, but his wife and children, were murdered as they came out, and when, moreover, this incident passed without legal investigation or punishment, it was a bad omen for the extension of liberty, etc., etc., to Malays and Tagals by simply setting over them the American flag. Upon a little serious examination the off-hand disposal of an important question of policy by the declaration that Americans can do anything proves to be only a silly piece of bombast, and upon a little reflection, we find that our hands are quite full at home of probblems, by the solution of which the peace and happiness of the American people could be greatly increased. The laws of nature and of human nature are just as valid for Americans as for anybody else, and if we commit acts, we shall have to take consequences, just like other people. Therefore prudence demands that we look ahead to see what we are about to do, and that we gauge the means at our disposal, if we do not want to bring calamity on ourselves and our children. We see that the peculiarities of our system of government set limitations on us. We cannot do things which a great centralized monarchy could do. The very blessings and special advantages which we enjoy, as 
compared with others, bring disabilities with them. That is the great fundamental cause of what I have tried to show throughout this lecture, that we cannot govern dependencies consistently with our political system, and that, if we try it, the state which our fathers founded will suffer a reaction which will transform it into another empire just after the fashion of all the old ones. That is what imperialism means. That is what it will be, and the democratic republic, which has been, will stand in history as a mere transition form like the colonial organization of earlier days.

And yet this scheme of a republic which our fathers formed was a glorious dream which demands more than a word of respect and affection before it passes away. Indeed, it is not fair to call it a dream or even an ideal. It was a possibility which was within our reach if we had been wise enough to grasp and hold it. It was favored by our comparative isolation, or, at least, by our distance from other strong states. The men who came here were able to throw off all the trammels of tradition and established doctrine. They went out into a wilderness, it is true, but they took with them all the art, science and literature which, up to that time, civilization had produced. They could not, it is true, strip their minds of the ideas which they had inherited, but, in time, as they lived on in the New World, they sifted and selected these ideas, retaining what they chose. Of the old world institutions also they selected and adopted what they chose and threw aside the rest. It was a grand opportunity to be thus able to strip off all the follies and errors which they had inherited, so far as they chose to do so. They had unlimited land with no feudal restrictions to hinder them in the use of it. Their idea was that they would never allow any of the social and political abuses of the old world to grow up here. There should be no manors, no barons, no ranks, no prelates, no idle classes, no paupers, no disinherited ones except the vicious. There were to be no armies except a militia, which would have no functions but those of police. They would have no court and no pomp; no orders, or ribbons, or decorations, or titles. They would have no public debt. They repudiated with scorn the notion that a public debt is a public blessing. If debt was incurred in war it was to be paid in peace and not entailed on posterity. There was to be no grand diplomacy, because they intended to mind their own business, and not be involved in any of the intrigues to which European statesmen were accustomed. There was to be no balance of power and no "reason of state" to cost the-life and happiness 
of citizens. The only part of the Monroe doctrine which is valid was their determination that the social and political systems of Europe should not be extended over any part of the the American Continent, lest people who were weaker than we should lose the opportunity which the new continent gave them to escape from those systems if they wanted to. Our fathers would have an economical government, even if grand people called it a parsimonious one, and taxes should be no greater than were absolutely necessary to pay for such a government. The citizen was to keep all the rest of his earnings, and use them as he thought best for the happiness of himself and his family. The citizen was, above all, to be insured peace and quiet while he pursued his honest industry and obeyed the laws. No adventurous policies of conquest or ambition, such as, in their belief, kings and nobles had forced, for their own advantage, on European states, would ever be undertaken by a free democratic republic. Therefore the citizen here would never be forced to leave his family, or to give his sons to shed blood for glory and to leave widows and orphans in misery for nothing. Justice and law were to reign in the midst of simplicity, and a government which had little to do was to offer little field for ambition. In a society where industry, frugality and prudence were honored, it was believed that the vices of wealth would never flourish.

We know that these beliefs, hopes and intentions have been only partially fulfilled. We know that, as time has gone on, and we have grown numerous and rich, some of these things have proved impossible ideals, incompatible with a large and flourishing society, but it is by virtue of this conception of a commonwealth that the United States has stood for something unique and grand in the history of mankind, and that its people have been happy. It is by virtue of these ideals that wehave been "isolated," isolated in a position which the other nations of the earth have observed in silent envy, and yet there are people who are boasting of their patriotism; because they say that we have taken our place now amongst the nations of the earth by virtue of this war. My patriotism is of the kind which is outraged by the notion that the United States never was a great nation until in a petty three months campaign it knocked to pieces a pour, decrepit bankrupt old state like Spain. To hold such an opinion as that is to abandon all American standards, to put shame and scorn on all that our ancestors tried to build up here, and to go over to the standards of which Spain is a representative. 